\title{
Optimalisasi Galian Excavator Pada Proyek Drainase Kelurahan Jingglong Kecamatan Sutojayan Kabupaten Blitar
}

\author{
Sugeng Arifina \\ Program Studi Teknik Sipil Fakultas Eksakta, Universitas Nahdlatul Ulama Blitar, Blitar, Indonesia \\ e-mail: sugengarifina@gmail.com
}

\begin{abstract}
Abstrak
Proyek dari lingkup pemerintahan selalu terikat kontrak dalam masa penyelesaian pelaksanaan pekerjaan. Optimalisasi pekerjaan pada suatu proyek sangatlah di perlukan guna untuk mempercepat dan mendapatkan keuntungan yang maksimal dalam melaksanakan suatu pekerjaan. Salah satu optimalisasi pekerjaan dapat di lakukan dengan cara menggunakan alat berat sebagai pengganti peralatan manual. Pada penelitian ini, membandingkan analisa SNI pada item pekerjaan galian yang telah di tentukan pada Proyek Pembangunan Drainase Kelurahan Jingglong Kecamatan Sutojayan Kabupaten Blitar dengan analisa Bina Marga. Penelitian ini bertujuan untuk mendapatkan selisih keuntungan dari harga satuan item pekerjaan. Metode penelitian menggunakan metode perhitungan manual dengan rumus perhitungan volume galian tanah untuk mengailkan jangka waktu dan anggaran biaya selama menggunakan excavator. Dari hasil penelitian dapat di simpulkan bahwa dengan menggunakan nalisa SNI Bina Marga volume pekerjaan adalah 171.29 m3 memerlukan jangka waktu penyelesaian 1.84 jam dengan harga satuan Rp. 30.931,53 setiap $1 \mathrm{m3}$. Sedangkan untuk analisa SNI Sumber Daya Air dengan volume pekerjaan adalah $171.29 \mathrm{m3}$ memerluka jangka waktu penyelesaian 13.78 hari dengan harga satuan Rp.56.000,00 setiap $1 \mathrm{m3}$.
\end{abstract}

Katakunci: Excavator, Harga Satuan, Percepatan Pekerjaan

\begin{abstract}
Abstrack
Projects from the scope of the government are always bound by a contract during the completion of the work. Optimization of work on a project is very necessary in order to speed up and get maximum benefits in carrying out a job. One of the optimization of work can be done by using heavy equipment instead of manual equipment. In this study, comparing the SNI analysis on excavation work items that have been determined in the Drainage Development Project, Jingglong Village, Sutojayan District, Blitar Regency with Bina Marga analysis. This study aims to obtain the difference in profit from the unit price of work items. The research method uses the manual calculation method with the formula for calculating the volume of soil excavation to increase the time period and budget for using the excavator. From the results of the study it can be concluded that by using the analysis of SNI Bina Marga the volume of work is $171.29 \mathrm{~m} 3$ requiring a completion time of 1.84 hours with a unit price of Rp. 30,931.53 per $1 \mathrm{~m} 3$. Meanwhile, for the analysis of SNI for Water Resources with a work volume of $171.29 \mathrm{~m} 3$ it requires a completion time of 13.78 days with a unit price of $R p .56,000.00$ per $1 \mathrm{m3}$.
\end{abstract}

Keywords: Excavator, Unit Price, Work Acceleration

\section{PENDAHULUAN}

Proyek dari lingkup pemerintahan selalu terikat kontrak dalam masa penyelesaian pelaksanaan pekerjaan. Pada umumnya proyek drainase atau saluran irigasi di Kabupaten Blitar untuk item pekerjaan tanah selalu menggunakan analisa harga satuan SNI Sumber Daya Air yaitu analisa galian tanah biasa hanya menggunakan tenaga kerja manusia dan peralatan manual. Tanpa menggunakan alat berat untuk mempercepat pelaksanaan pekerjaan. Padahal untuk proyek akhir tahun percepatan pekerjaan sanggatlah penting, mengingat waktu pelaksanaan pekerjaan yang begitu singkat. Penelitian ini dilakukan pada proyek - proyek Pembangunan Drainase Kelurahan Jingglong Kecamatan Sutojayan Kabupaten Blitar. Proyek ini terdapat beberapa item pekerjaan, salah satunya adalah item pekerjaan tanah. Pada item pekerjaan tanah terdapat sub item yaitu galian tanah dan pengurugan tanah kembali. Upaya 
mempercepat pekerjaan tersebut, maka perlu menggunakan alat berat. Excavator adalah salah satu alat berat yang tepat digunakan untuk mempercepat pekerjaan galian tanah.

Produktivitas adalah kemampuan alat dalam satuan waktu (m3/jam), dan alat berat merupakan faktor penting didalam proyek terutama proyek- proyek konstruksi dengan skala yang besar. Alat berat bertujuan untuk memudahkan pekerja dalam menyelesaikan pekerjaan agar lebih cepat dan efisien. Karena berpengaruh dengan item pekerjaan setelah pekerjaan galian tanah. Mengingat jangka waktu penyelesaian sangatlah singkat [1]. Salah satu alat penggali yaitu excavator. Excavator adalah alat untuk penggali, pengangkat maupun pemuat tanpa harus berpindah tempat menggunakan tenaga power take off dari mesin yang dimilki, yang terdiri dari tiga bagian utama yaitu bagian atas yang dapat berputar (revolving unit), bagian bawah untuk berpindah tempat (travelling unit) dan bagian-bagian tambahan (attachment) yang dapat diganti yang sesuai [2].

Selain penambahan alat berat sebagai pengganti alat manual yang harus di perhatikan adalah analisa harga satuan pekerjaan. Analisa harga satuan pekerjaan merupakan analisa material, upah, dan peralatan untuk membuat satuan pekerjaan yang di atur dalam SNI maupun BOW. Koefisien kuantitas sudah di tentukan dalam analisa SNI maupun BOW. Kajian yang perlu dilakukan yaitu analisa mana yang tepat untuk mempercepat pekerjaan dan mendapatkan untung dari anggaran biaya. Beberapa peneliti terdahulu juga telah menganalisis tentang Produktivitas dan waktu penggunaan alat berat excavator pada pekerjaan galian tanah [3], Analisis biaya penggunaan alat berat pada pekerjaan tanah (Studi Kasus Perencanaan Bandar Udara Lokasi Desa Pusungi Kec. Ampana Tete Kab. Tojo Una-una, Sulawesi Tengah) [4]. Optimalisai penggunaan alat berat pada pekerjaan galian tanah di proyek tol Nganjuk-Kertosono [5] selain itu kuantitas penggunaan alat berat untuk item pekerjaan galian dan timbunan (studi kasus: peningkatan jalan kecamatan ciruas-lebakwangi-pontang-tirtayasa) Kabupateng Serang [6].

Berdasarkan penelitian tersebut di atas, fokus penelitian ini adalah Optimalisasi Galian Excavator Pada Proyek Drainase. Tujuan penelitian ini guna untuk mengetahui berapa lama jangka waktu yang di butuhkan dan berapa selisih anggaran biaya yang harus di keluarkan pada item pekerjaan galian tahan menggunakan alat berat excavator sebagai penunjang percepatan pekerjaan sebagai pengganti alat manual pada proyek pembangunan drainase Kelurahan Kelurahan Jingglong Kecamatan Sutojayan Kabupaten Blitar.

\section{METODE PENELITIAN}

Metode deskriptif kualitatif merupakan teknik analisis data yang dilandaskan pada filsafat postpositivisme yang digunakan untuk meneliti kondisi objek yang alamiah di mana peneliti berperan sebagai instrumen kunci, pengambilan sampel, dan sumber data yag bersifat induktif atau kualitatif, serta hasil kualitatif lebih menekankan makna dari pada generalisasi [7] Sampel pada penelitian ini adalah item pekerjaan galian tanah menggunakan tenaga kerja manual yang di ganti dengan alat berat excavator sebagai penunjang percepatan pekerjaan pada proyek pembangunan drainase Kelurahan Kelurahan Jingglong Kecamatan Sutojayan Kabupaten Blitar. Untuk memperoleh data yang akurat penulis melakukan observai wawancara langsung di lokai pekerjaan proyek pembangunan drainase Kelurahan Kelurahan Jingglong Kecamatan Sutojayan Kabupaten Blitar.

Analisis data yaitu proses mencari dan menyusun secara sistematis data yang telah diperoleh dari hasil wawancara, catatan lapangan, dan dokumentasi [7]. Data yang di proleh kemudian di analisis secara kualitatif dengan memadukan secara menyeluruh. Analisis ini bertujuan untuk mengetahui jangka waktu penyelesaian dan anggaran biaya pada item pekerjaan galian tanah pada proyek pembangunan drainase Kelurahan Kelurahan Jingglong Kecamatan Sutojayan Kabupaten Blitar. Setelah data di terima dapat di simpulkan dari keseluruhan data yang telah di peroleh. 
Untuk memperjelas penelitian di gambarkan dengan bagan alir di bawah ini:

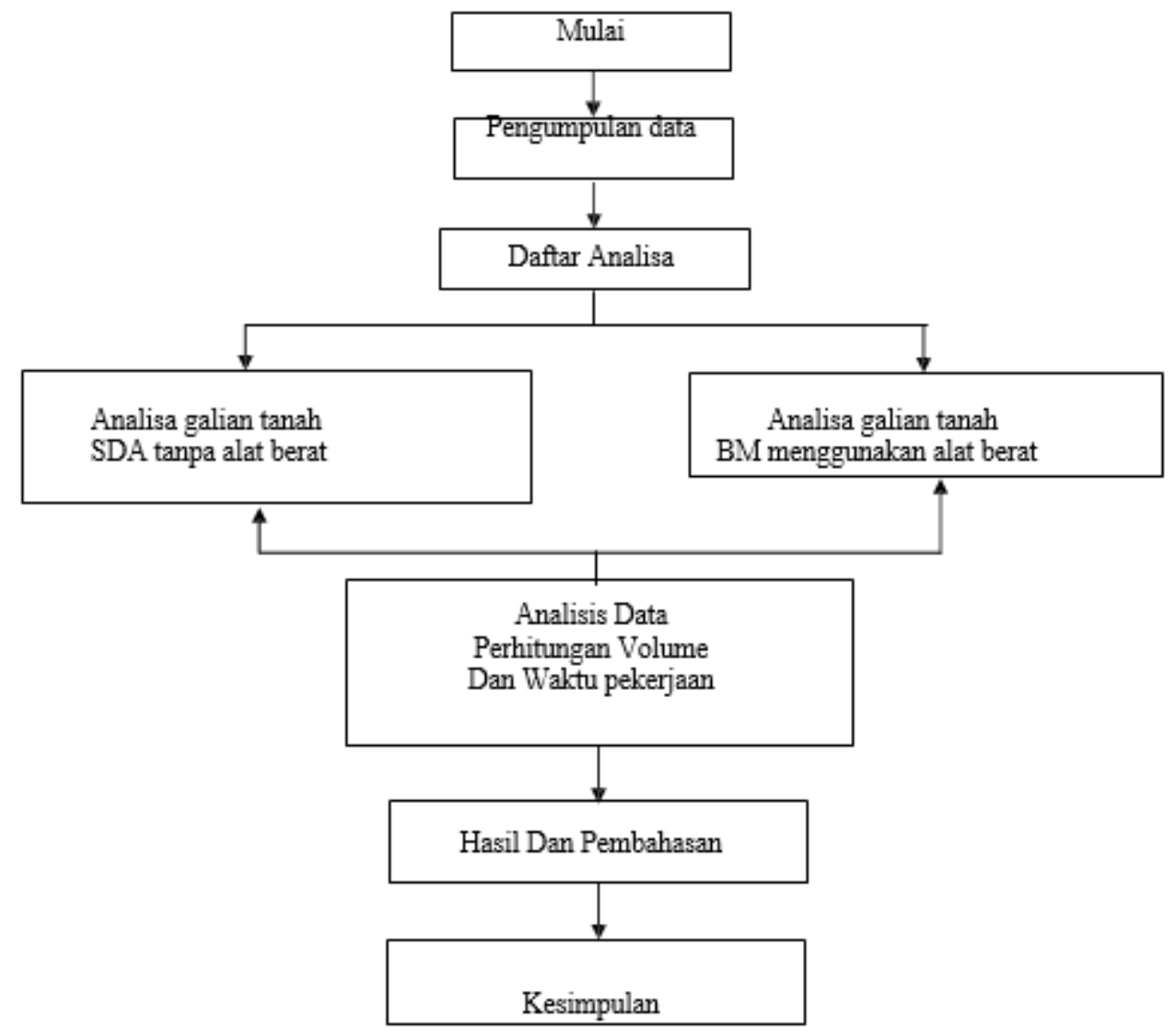

Gambar 1. Skema penelitian

\section{HASIL DAN PEMBAHASAN}

Data Umum Proyek

Nama Kegiatan

:Fasilitasi dan Koordinasi Pengelolaan Drainase Lingkungan

Nama Pekerjaan

:Pembangunan /Pemeliharaan Saluran Drainase Kel. Jingglong Kec.

Sutojayan

Pemilik Proyek

:Dinas Perumahan Dan Kawasan Permukiman Kabupaten Blitar

Lokai Pekerjaan

:Kec. Sutojayan Kab .Blitar

Kontraktor Pelaksana

Konsultan Pengawas

:CV. TARING PADI LESTARI

Waktu Pelaksanaan

:CV. MITRA KARYA MANDIRI

Volume Galian

:60 hari kalender

$: 171.29 \mathrm{~m} 3$

\section{Definisi Analisis}

Analisis merupakan perumusan guna menetapkan harga dan upah masing-masing dalam bentuk harga satuan. Dalam menyusun biaya diperlukan daftar-daftar sebagai beriku:

1. Rencana Anggaran Biaya

2. Daftar Upah

3. Daftar Sewa Alat

4. Daftar Analisa Harga Satuan 


\section{Rencana Anggaran Biaya}

Rencana Anggaran Biaya proyek adalah menghitung banyaknya biaya yang di perlukan untuk bahan dan upah tenaga kerja berdasarkan analisis, serta biaya-biaya lain yang berhubungan dengan pelaksanaan pekerjaan atau proyek [8].

\section{Daftar Upah}

Besarnya upah kerja untuk operator pada excavator, dan sopir pada dump truck adalah tergantung dari lokasi pekerjaan, perusahaan yang bersangkutan, peraturan yang berlaku di lokasi, dan kontrak kerja antara dua pihak tersebut. Pada dasarnya upah untuk pekerja di hitung dalam besarnya uang yang dibayarkan per jam kerjanya (Rp/jam).

\section{Daftar Sewa Alat}

Tidak semua peralatan konstruksi dimiliki oleh kontraktor. Dalam menyelesaikan pekerjaan-pekerjaan tertentu, diperlukan peralatan-peralatan khusus yang diperoleh dengan cara menyewa. Biaya penyewaan alat berat tersebut dihitung dalam biaya per jam. Dalam satu bulan biasanya ditentukan batas penyewaan minimum per alat berat. Biaya penyewaan alat bervariasi, tergantung dari jenis dan tipe alat yang akan disewa dan juga tergantung dari tempat alat itu disewa.

\section{Daftar Analisa Harga Satuan}

Analisis harga satuan pekerjaan meru- pakan analisis material, upah tenaga kerja, dan peralatan untuk membuat satuan-satuan pekerjaan tertentu yang diatur dalam SNI maupun BOW. Analisis harga satuan bahan, ialah menghitung volume masing-masing bahan, serta biaya yang dibutuhkan. Kebutuhan bahan ialah besarnya jumlah bahan yang dibutuhkan untuk menyelesaikan yang dibutuhkan untuk menyelesaikan bagian pekerjaan dalam satuan pekerjaan.

Analisis harga satuan alat adalah menghitung banyaknya alat yang diperlukan dalam suatu pekerjaan dengan meninjau besarnya volume pekerjaan dan efektivitas hari kerja maksimal sehingga dapat diketahui jumlah alat yang harus disediakan dan berapa hari yang dibutuhkan untuk menyelesaikan suatu pekerjaan. Analisis Harga Satuan Upah Kerja, ialah menghitung banyaknya tenaga yang diperlukan serta besarnya biaya yang dibutuhkan untuk pekerjaan tersebut. Kebutuhan tenaga kerja ialah besarnya jumlah tenaga yang dibutuhkan untuk menyelesaiakan bagian pekerjaan dalam suatu pekerjaan.

\section{Hasil Pengelolaan Data}

\section{Berdasarkan Metode Analisa Harga Satuan SNI}

Tabel 1. Analisa SNI Galian Tanah Sumber Daya Air

\begin{tabular}{|c|c|c|c|c|c|c|c|}
\hline \multirow[t]{15}{*}{$\begin{array}{l}\text { T.06 } \\
\text { T.06.a1 }\end{array}$} & \multicolumn{7}{|c|}{$\begin{array}{l}\text { Galian Tanah Biasa } \\
1 \mathrm{~m} 3 \text { galian tanah biasa sedalam } \leqslant 1 \mathrm{~m}\end{array}$} \\
\hline & No. & Uraian & Kode & Satuan & Koefisien & $\begin{array}{l}\text { Harga Satuan } \\
\text { (Rp) }\end{array}$ & $\begin{array}{l}\text { Jumlah Harga } \\
\text { (Rp) }\end{array}$ \\
\hline & 1 & 2 & 3 & 4 & 5 & 6 & 7 \\
\hline & A. & TENAGA & & & & & \\
\hline & 1 & Pekerja & L.01 & $\mathrm{OH}$ & 0.5630 & $80,000.00$ & $45,040.00$ \\
\hline & 2 & Mandar & L.04 & $\mathrm{OH}$ & 0.0563 & $105,000.00$ & $5,911.50$ \\
\hline & \multicolumn{6}{|c|}{ JUMLAH HARGA TENAGA KERIA } & $50,951.50$ \\
\hline & B. & BAHAN & & & & & \\
\hline & \multicolumn{6}{|c|}{ JUMLAH HARGA BAHAN } & - \\
\hline & c. & PERALATAN & & & & & \\
\hline & \multicolumn{6}{|c|}{ JUMLAH HARGA PERALATAN } & - \\
\hline & D & \multirow{2}{*}{\multicolumn{2}{|c|}{$\begin{array}{l}\text { Jumlah harga tensgs, bahan dan peralatan }(A+B+C) \\
\text { Overhead dan profit (Comtoh } 15 \% 6)\end{array}$}} & & & & $50,951.50$ \\
\hline & $E$ & Overhead dan profit (Contoh 15\%) & & \multicolumn{3}{|c|}{$10 \% 6 \mathrm{XD}$} & $5,095.15$ \\
\hline & $F$ & \multirow{2}{*}{\multicolumn{5}{|c|}{$\begin{array}{l}\text { Harga satuan pekerjaan Per- } m^{2}(D+E) \\
\text { Pembulatan }\end{array}$}} & $56,046.65$ \\
\hline & & & & & & & $56,000.00$ \\
\hline
\end{tabular}


Tabel 2. Analisa SNI Galian Tanah Bina Marga

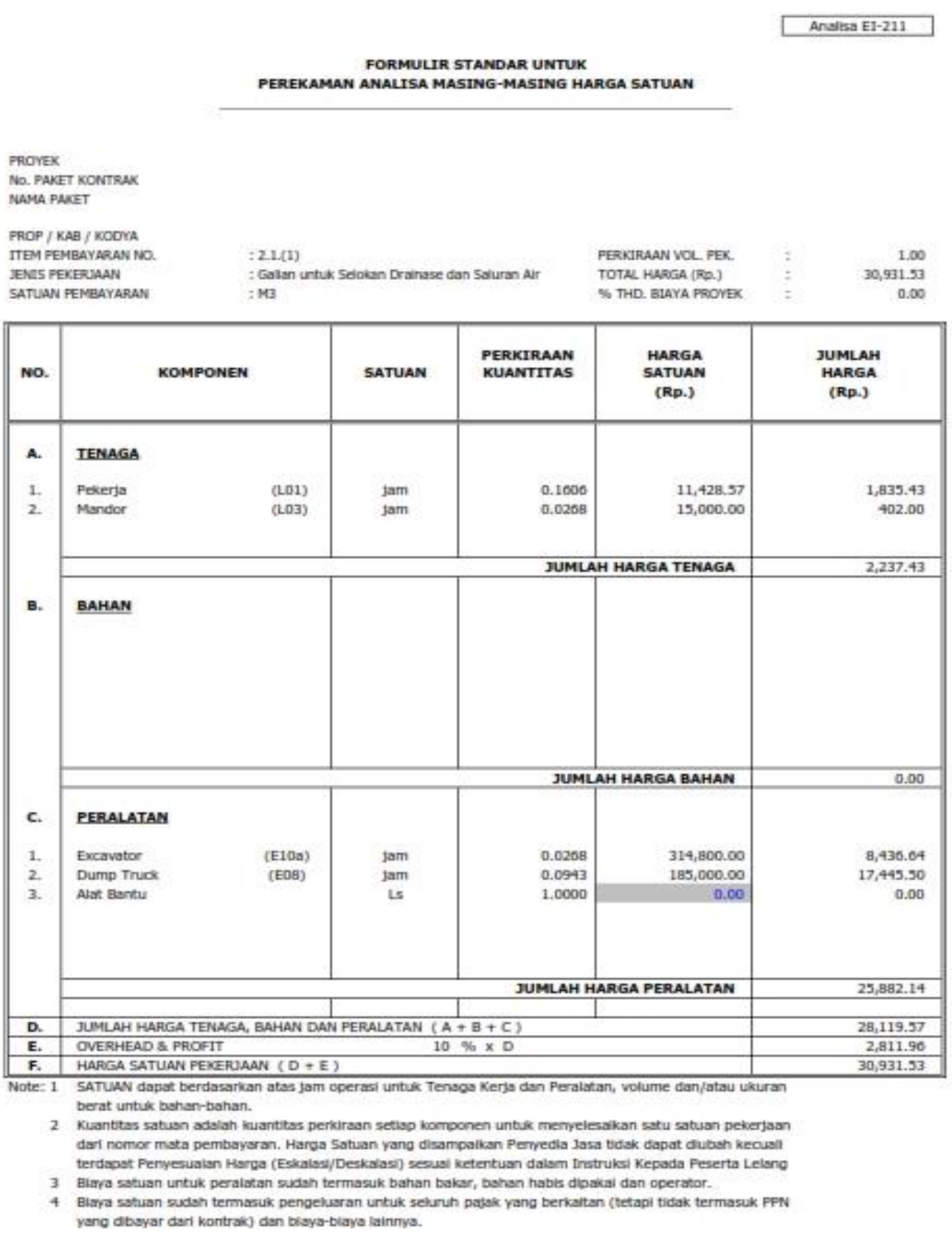

\section{Selisih Harga Satuan}

Perolehan seisih harga satuan pada item pekerjaan galian di rumuskan dengan:

Selisih harga satuan = harga satuan tertinggi - harga satuan terendah. Selisih harga satuan untuk item pekerjaan galian antara analisa SNI SDA dan analisa SNI BM Rp.56.000,00-Rp. 30.931,53 $=$ Rp.25.068,47. Dari selisih harga satuan cukup jelas jika menggunakan alat berat keuntangan profit lebih besar di banding menggunakan analisa tenaga kerja manual. Jika selisih harga satuan di kalikan dengan total volume maka $=$ Rp.25.068,47 x $171.29 \mathrm{~m} 3=\mathrm{Rp} \cdot 4.293 .979 .01$. Untuk mengetahui jangka waktu percepatan pelaksanaan item pekerjaan galian tanah mengunakan excavator dapat di hitung dengan produktivitas alat berat, perhitungan volume dan waktu pemakaian alat. 
Jumlah Perhitungan Produktivitas excavator

$\begin{array}{lll}\text { Kapasitas bucket (q1) } & =1 \mathrm{~m} 3 \\ \text { Faktor bucket (K) } & =0.8 \\ \text { Efisiensi kerja (E) } & =0.81 \\ \text { Jam kerja efektif } & =7 \mathrm{jam} \\ \text { Jnis tanah } & =\text { tanah biasa } \\ \text { Waktu gali } & =6 \text { detik } \\ \text { Waktu putar } & =5 \text { detik } \\ \text { Waktu buang } & =4 \text { detik } \\ \text { Rata-rata kedalaman galian } & =0.81 \mathrm{~m} \\ \text { Maksimum galian } & =4 \mathrm{~m} \\ \text { Presentase kedalaman galian } & =0.81 \mathrm{~m} / 4 \mathrm{~m}=0.2=20 \% \\ \text { Produksi per siklus (q) } & =\mathrm{q} 1 \times \mathrm{K}=1 \times 0.8=0.8 \mathrm{~m} 3 \\ \text { Waktu siklus (Cm) } & =\text { waktu gali }+ \text { waktu putar } \times 2+\text { waktu buang } \\ & =6+(5 \times 2)+4\end{array}$

Perhitungan produksi excavator dapat di hitung dengan rumus:

$\mathrm{P}=\frac{\mathrm{q} \times 3600 \times \mathrm{E}}{\mathrm{Cm}}=\frac{0.8 \times 3600 \times 0.81}{20} \times 0.8=93.312 \mathrm{~m} 3 / \mathrm{jam}$

Produksi excavator per hari $=93.312 \times 7$ jam $=653.184 \mathrm{~m} 3 /$ hari

Untuk mengerjakan volume galian tanah pada proyek Saluran Drainase Kel. Jingglong Kec. Sutojayan adalah volume $=\underline{171.29}=1.84 \mathrm{jam}$

$$
\mathrm{P} \quad 93.312
$$

Sedangkan jika galian tanah di kerjakan secara manual tanpa alat berat menggunakan analisa SDA adalah volume $\mathrm{x}$ koef pekerja $/$ jam kerja $=171.29 \times 0.563 / 7=13.78$ hari.

Jadi selain untuk mendapat keuntungan profit dari anggaran biaya pada pekerjaan galian menggunakan analisa SNI Bina Marga juga juga lebih cepat dalam jangka waktu pelaksanaan pekerjaan.

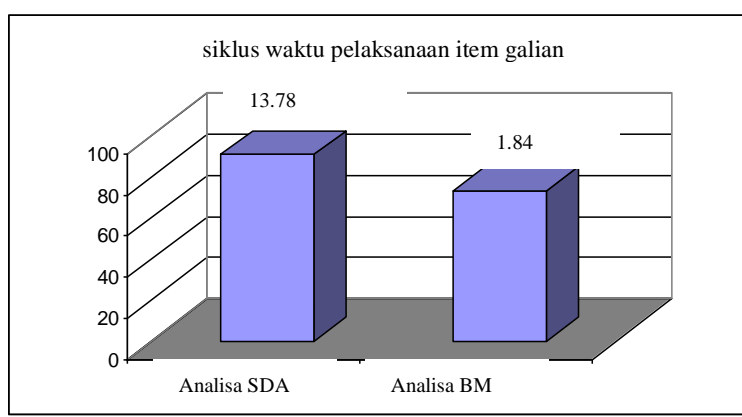

Gambar 2 Grafik perbandingan

\section{KESIMPULAN}

Berdasarkan hasil analisa data dari proyek Pembangunan Drainase Kelurahan Jingglong Kecamatan Sutojayan Kabupaten Blitar untuk item pekerjaan galian menggunakan nalisa SNI Bina Marga dengan volume pekerjaan adalah $171.29 \mathrm{~m} 3$ memerlukan jangka waktu penyelesaian 1.84 jam dengan harga satuan Rp. 30.931,53 setiap $1 \mathrm{~m} 3$. Sedangkan untuk analisa SNI Sumber Daya Air dengan volume pekerjaan adalah $171.29 \mathrm{~m} 3$ memerluka jangka waktu penyelesaian 13.78 hari dengan harga satuan Rp.56.000,00 setiap $1 \mathrm{~m} 3$. Jadi untuk analisa harga 
satuan SNI Bina Marga lebih efisien di gunakan untuk mempercepat pekerjaan dan mendapatkan keuntungan yang lebih besar.

\section{DAFTAR PUSTAKA}

[1] Rostiyanti, Produktivitas Alat - Alat Berat Pada Proyek Konstruksi, Jakarta: Penerbit Rineka Cipta, 1999.

[2] Rochmanhadi, Metode Penelitian pendidikan Pendekatan Kuantitatif, Kualitatif dan R \& D, Bandung: Alfabeta, 1986.

[3] F. D, "Analisis Produktivitas dan Waktu Penggunaan Alat Berat Excavator Pada Pekerjaan Galian Tanah," in Seminar Nasional Pakar Ke 1, ., 2018.

[4] T. S.P., "Analisis Biaya Penggunaan Alat Berat Pada Pekerjaan Tanah," Jurnal Sipil Statik, vol. 1, no. 12, pp. 764 - 773, 2012.

[5] Ramadhani, Optimalisasi Penggunaan Alat Berat Pada Pekerjaan Galian Tanah di Proyek Tol Nganjuk - Kertosono, Malang: Universitas Brawijaya, 2017.

[6] H. B, "Kuantitatif Penggunaan Alat Berat untuk Item Pekerjaan Alian dan Timbunan (Studi kasus : Peningkatan Jalan Kecamatan Cirual - Lebakwangi - Pontang Tirtayasa) Kabupaten Serang," Jurnal JOSCE, vol. 2, no. 1, pp. 29 - 40, 2020.

[7] Sugiyono, Metode Penelitian Pendidikan Pendekatan Kuantitatif, Kualitatif dan R\&D, Bandung: Alfabeta, 2013.

[8] Mukomoko, Dasar Penyusunan Anggaran Biaya Bangunan, Jakarta: Penerbit Gaya Media Pratama, 2007. 